Original Research Article

\title{
Knowledge, attitude and practices of general practitioners about use of antiviral drugs in viral infections other than HIV
}

\author{
Shirish G. Beri, Harshavardhan S. Bhide, Priti P. Dhande*, Aishwarya Raman
}

\begin{abstract}
Department of Pharmacology, Bharati Vidyapeeth (Deemed to be) University Medical College, Pune, Maharashtra, India
\end{abstract}

Received: 02 February 2018 Accepted: 17 May 2018

*Correspondence to: Dr. Priti P. Dhande, Email: ppdhande@yahoo.com

Copyright: (C) the author(s), publisher and licensee Medip Academy. This is an openaccess article distributed under the terms of the Creative Commons Attribution NonCommercial License, which permits unrestricted noncommercial use, distribution, and reproduction in any medium, provided the original work is properly cited.

\begin{abstract}
Background: Antiviral drugs for viral infections other than HIV are effective only for hepatitis, herpes and influenza. It has been observed that general practitioners (GPs) treat viral infections with antibiotics. The use of antibiotics in viral infections is not rational. Hence, authors conducted this study to assess the Knowledge, Attitude and Practices of General Practitioners (GPs) about treatment of viral infections other than HIV.

Methods: It was a descriptive, observational, cross- sectional study among 100 GPs in Southern Pune. A pretested questionnaire was used to assess their knowledge, attitude and practices about treatment of viral infections other than HIV. Prior informed written consent was taken from the GPs who were grouped under MBBS, BHMS and BAMS categories according to their qualifications. Correct answers among these groups were analysed using chi-square test, Spearman's coefficient test and ANOVA.

Results: The percentages of correct answers in the groups were comparable.56\% GPs have poor knowledge of Influenza treatment.30-36\% do not treat Herpes genitalis and zoster with antiviral drugs. Authors found that $44 \%, 30 \%$ and $28 \%$ of total GPs don't have proper knowledge, attitude and practice respectively about common viral infections other than HIV and antiviral drugs.

Conclusions: GPs are significantly unaware about rational use of antiviral drugs. They have poor knowledge about management of influenza.
\end{abstract}

Keywords: Anti-viral, General practitioners (GPs), Hepatitis, Herpes, Influenza

\section{INTRODUCTION}

Most viral diseases, with the exception of those caused by human immunodeficiency virus, are self-limited illnesses that do not require specific antiviral therapy. ${ }^{1}$ The currently available antiviral drugs target three main viruses. Groups of viruses: herpes, hepatitis, and influenza. Primary care physicians (General practitioners) are most important Heath professionals who come across patients suffering from various viral infections.

Many common viruses like Adenoviruses (upper respiratory tract infections and eye infections), papillomavirus (warts), picorna viruses (polio), paramyxoviruses (measles, rubella), rotavirus (gastroenteritis in children), arenavirus (viral meningitis) and coronavirus (respiratory tract infections) have no effective antiviral drugs available. However, the viral diseases like mumps, measles, polio, rabies, rotaviral gastroenteritis are successfully controlled by effective vaccination..$^{2-5}$

It is obvious that most common viral infections are respiratory tract infections which present with fever and respiratory symptoms. Present antiviral drugs are not effective for these infections. It has been observed that general practitioners (GPs) treat these infections with 
drugs for symptomatic relief and very often they add antibacterial or antibiotics. ${ }^{6}$ The use of antibiotics in viral infections is not rational.

GPs also come across viral infections for which antiviral drugs are available such as chicken pox, herpes zoster or influenza. All these infections are self-limited in immunocompetent patients hence no antiviral drugs are required. Only immunocompromised patients require active antiviral treatment. Another stumbling block is that in majority of acute viral infections, viral replication is already at its peak when symptoms appear. ${ }^{7}$ Hence staring the therapy after appearance of symptoms many times is hardly effective. GPs should have sound knowledge of available antiviral drugs, their indications and exact time of initiation of therapy. In case of HIV infection, HIV positive patients are mostly referred to anti-retroviral centres. Even if not referred, treatment of HIV infection by anti-retroviral drugs has well known and clearly defined guidelines and therefore there it is expected to be uncommon that GPs will treat HIV patients by antiviral drugs in an incorrect manner.

In order to know the perception of GPs towards viral infections this study of Knowledge, Attitude and Practice of treatment of viral infections other than HIV infections by GPs is undertaken.

\section{METHODS}

Our study was descriptive, observational, cross-sectional study. The study has been conducted in southern Pune. Authors included 104 patients in this study. All general practitioners holding different graduate degrees like MBBS, BHMS and BAMS have been included. Postgraduate holders in Ayurveda and Homeopathy had also been included. No post-graduate holder in Allopathy had been included. Prior approval from institutional ethics committee had been taken. Authors made a questionnaire comprising of close-ended questions of knowledge, attitude and practice regarding use of antiviral drugs in viral infections other than HIV. The questionnaire was presented to 10 general practitioners and got it filled by them, authorsmade modifications according to their suggestions and references from previous similar KAP studies. ${ }^{8,9}$ The final questionnaire consisted of 23 questions. 10 of knowledge, 6 of attitude and 7 of practice was prepared. The 9th question of knowledge was not of close-ended type and was regarding various modalities through which GPs update their knowledge including CMEs, medical journals, internet and their different permutations and combinations. Question set of knowledge had three options namely 'yes, 'no' and 'don't know', in case of attitude, 'agree', 'disagree' and 'uncertain' and about practice, 'yes' and 'no'. Responses of 'don't know' and 'uncertain' was considered as false. Prior informed written consent was taken. This questionnaire was presented to every GP either by approaching his/her clinic and during CMEs conducted in Bharati hospital. The study and questionnaire were clearly explained to the GPs. Authors explained how to fill-up the questionnaire. 15-20 minutes time had been given to fill up questionnaire. It was also ensured that no influence will be made over GPs for their free opinions.

Data was coded in excel sheet. Answers were analysed by their correctness as per guidelines mentioned in the references. Results were expressed by percentage of correct answers. Statistical analysis was done for comparison of knowledge, attitude and practices regarding the same between MBBS, BHMS and BAMS GPs with the help of Chi square test, Spearman's coefficient test, ANOVA and Tukey's test.

\section{RESULTS}

Authors divided GPs into 3 groups, namely MBBS, BHMS and BAMS.46 GPs were under BAMS category, 31 under BHMS and 27 under MBBS. Responses from these GPs were analysed by percentage of correctness of answers of all questions. Answer to the 10th question of knowledge is represented independently, in the form of a graph.

Findings regarding all remaining questions are represented in the form of three tables relating with knowledge, attitude and practices regarding use of antiviral drugs in viral infections other than HIV. The appropriate answers to all the questions asked are presented against the respective questions in the tables in round brackets.

Table 1 shows that about $30 \%$ of the study participants were unaware that all viral infections cannot be treated by antiviral drugs and that these drugs have more adverse effects than antibacterial agents (64\%). 41\% BAMS general practitioners lacked knowledge about ineffectiveness of antiviral drugs against common cold, where BHMS and MBBS practitioners were found to be more knowledgeable in this aspect.

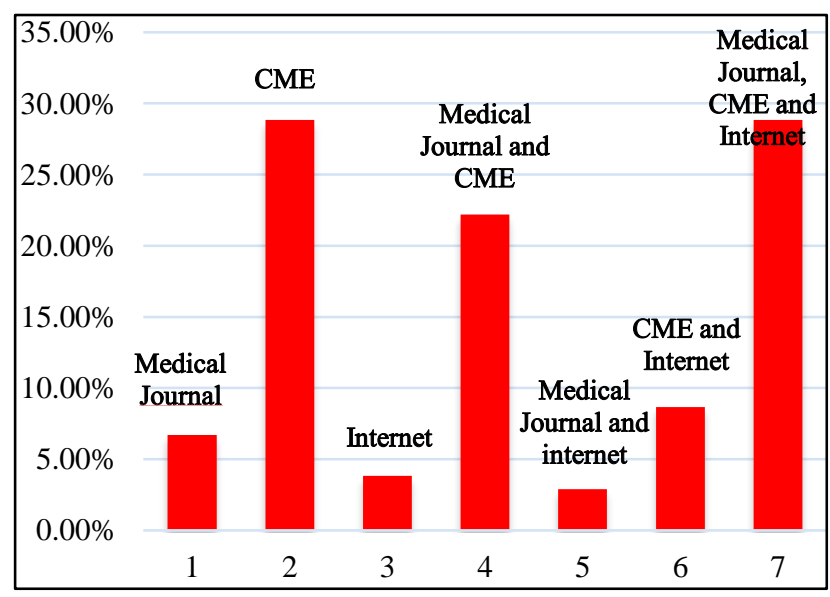

Figure 1: Percentage of GPs updating knowledge from various modalities.

Table 2 depicts that nearly 50\% of BAMS and BHMS participants felt that all patients with chicken pox needed 
antiviral drugs. Similarly, about $25 \%$ of each category of GPs agreed that Tamiflu is to be used in all patients of influenza. Majority of the GPs $(64 \%)$ answered that it was clinically difficult to differentiate viral infections from bacterial infections. It was found that $87 \%$ of BHMS participants used acyclovir or similar drugs in all cases of herpes zoster, whereas this usage was less found in BAMS and MBBS GPs. Some $(31 \%)$ of the study participants were found to treat Hepatitis B and C patients on their own with antiviral drugs.

The Figure 1 shows that majority of GPs (28\%) update their knowledge by CMEs while only few GPs update their knowledge by internet, medical journals and combinations of all these modalities.

Table 1: Participant's knowledge regarding use of antiviral drugs and viral infections other than HIV.

\begin{tabular}{|c|c|c|c|}
\hline \multirow{2}{*}{$\begin{array}{l}\text { GP's knowledge about antiviral drug use for viral infections } \\
\text { other than HIV }\end{array}$} & \multicolumn{3}{|c|}{ No. of participants given correct answers $\mathbf{N}(\%)$} \\
\hline & BAMS (46) & BHMS (31) & MBBS (27) \\
\hline All viral infections can be treated by antiviral drugs (No) & $29(63 \%)$ & $22(71 \%)$ & $20(74 \%)$ \\
\hline Antiviral drugs can also work against bacterial infections (No) & $43(93.5 \%)$ & $26(84 \%)$ & $25(92.5 \%)$ \\
\hline Antiviral drugs are costly (Yes) & $26(56.5 \%)$ & $18(58 \%)$ & $17(63 \%)$ \\
\hline Antiviral drugs have more adverse effects than antibacterial (Yes) & $17(37 \%)$ & $7(22.5 \%)$ & $13(48 \%)$ \\
\hline Antiviral drugs can also be used to prevent influenza (Yes) & $12(26 \%)$ & $17(55 \%)$ & $9(33 \%)$ \\
\hline $\begin{array}{l}\text { Antiviral drugs only work if taken within first } 48 \mathrm{hrs} \text { of influenza } \\
\text { (Yes) }\end{array}$ & $18(39 \%)$ & $17(55 \%)$ & $10(37 \%)$ \\
\hline $\begin{array}{l}\text { Antiviral drugs decrease amount of time of patient is sick with } \\
\text { influenza (Yes) }\end{array}$ & $18(39 \%)$ & $16(51.5 \%)$ & $9(33 \%)$ \\
\hline $\begin{array}{l}\text { Antiviral drugs are effective in the treatment of common cold } \\
\text { (No) }\end{array}$ & $27(59 \%)$ & $26(84 \%)$ & $23(85 \%)$ \\
\hline Antiviral drugs are available over the counter (No) & $25(54 \%)$ & $18(58 \%)$ & $14(52 \%)$ \\
\hline
\end{tabular}

Table 2: Participant's attitude regarding use of antiviral drugs and viral infections other than HIV.

\begin{tabular}{|c|c|c|c|}
\hline \multirow{2}{*}{$\begin{array}{l}\text { GP's attitude about antiviral drugs for viral infections other } \\
\text { than HIV }\end{array}$} & \multicolumn{3}{|c|}{ No. of participants given correct answers $\mathbf{N}(\%)$} \\
\hline & BAMS (46) & BHMS (31) & MBBS (27) \\
\hline $\begin{array}{l}\text { Every GP should have adequate knowledge of common viral } \\
\text { infections (Agree) }\end{array}$ & $46(100 \%)$ & $30(97 \%)$ & $24(89 \%)$ \\
\hline $\begin{array}{l}\text { All patients with chicken pox should receive antiviral drugs } \\
\text { (Disagree) }\end{array}$ & $23(50 \%)$ & $15(48.5 \%)$ & $18(66.5 \%)$ \\
\hline $\begin{array}{l}\text { All patients with herpes zoster(shingles) must be treated with } \\
\text { antiviral drugs (Agree) }\end{array}$ & $29(63 \%)$ & $28(90 \%)$ & $21(78 \%)$ \\
\hline $\begin{array}{l}\text { Use of Tamiflu (oseltamivir) in all patients of influenza } \\
\text { (Disagree) }\end{array}$ & $34(74 \%)$ & $24(77.5 \%)$ & $20(74 \%)$ \\
\hline $\begin{array}{l}\text { Immediate reporting of confirmed cases of H1N1 influenza a } \\
\text { dengue fever is essential (Agree) }\end{array}$ & $38(82.5 \%)$ & $27(87 \%)$ & $22(81.5 \%)$ \\
\hline $\begin{array}{l}\text { It is not easy to differentiate clinically viral infections from } \\
\text { bacterial infections (Disagree) }\end{array}$ & $17(34 \%)$ & $10(32 \%)$ & $12(44.5 \%)$ \\
\hline
\end{tabular}

Table 3: Participant's practices regarding use of antiviral drugs and viral infections other than HIV.

\begin{tabular}{|c|c|c|c|}
\hline \multirow{2}{*}{$\begin{array}{l}\text { GP's practices regarding use of antiviral drugs in the } \\
\text { treatment of viral infections by viruses other than HIV }\end{array}$} & \multicolumn{3}{|c|}{ No. of participants given correct answers $\mathbf{N}(\%)$} \\
\hline & BAMS (46) & BHMS (31) & MBBS (27) \\
\hline Do you use antibiotics in cases of viral infections? (No) & $30(65 \%)$ & $24(77.5 \%)$ & $16(59 \%)$ \\
\hline Do you use antiviral drugs in all patients of chicken pox? (No) & $32(69.5 \%)$ & $22(71 \%)$ & $19(70.5 \%)$ \\
\hline $\begin{array}{l}\text { Do you use acyclovir or similar drugs in all cases of herpes } \\
\text { zoster? (Yes) }\end{array}$ & $32(69.5 \%)$ & $27(87 \%)$ & $13(48 \%)$ \\
\hline Do you use antibiotics in common cold? (No) & $34(74 \%)$ & $27(87 \%)$ & $23(85 \%)$ \\
\hline Do you manage hepatitis B/C patients with antiviral drugs? (No) & $36(78 \%)$ & $18(58 \%)$ & $19(70.5 \%)$ \\
\hline $\begin{array}{l}\text { Are you using Tamiflu (oseltamivir) in all patients of influenza? } \\
\text { (No) }\end{array}$ & $41(89 \%)$ & $25(80.5 \%)$ & $22(81.5 \%)$ \\
\hline Do you treat herpes genitalis with antiviral drugs? (Yes) & $28(61 \%)$ & $21(67.5 \%)$ & $17(63 \%)$ \\
\hline
\end{tabular}




\section{DISCUSSION}

In this study, it was found that all categories of general practitioners lacked knowledge, attitude and practice regarding use of antiviral drugs in viral infections. Authors divided the findings of the study into positive and negative findings.

\section{Negative findings found}

General knowledge of common viral infections and commonly prescribed antiviral drugs: Participants were unaware that all viral infections cannot be treated by antiviral drugs. ${ }^{1}$ The fact that antiviral drugs have greater side effects than antibacterial drugs was not acceptable by majority (64\%) of GPs. ${ }^{1,7}$ In viral infections, antibiotics are of no use but significant fraction of GPs accepted that they treated these infections by antibiotics. Viral infections are easily differentiable from bacterial infections because viral infections are characterized by nonspecific symptoms like fever, generalized body ache, paraesthesia, headache, malaise and bacterial infections have site specific symptoms but nearly $30 \%$ GPs disagreed with this point. As more than $40 \%$ of BAMS practitioners lacked knowledge about ineffectiveness of antiviral drugs in common cold, many of them even treated this condition with antiviral drugs (Table 3). ${ }^{1,7}$

Antiviral drugs are highly effective in prevention of influenza but most of GPs thought otherwise. ${ }^{10-12}$ Although not statistically significant, BHMS practitioners had better knowledge on this than BAMS and MBBS GPs. It is known that antiviral drugs for influenza are effective only if given within first $48 \mathrm{hrs}$ but majority of GPs did not know this. Major fraction of GPs did not know the fact that antiviral drugs can only reduce duration of illness of influenza. ${ }^{13-15}$ Treatment of influenza by antiviral drugs is applicable only when patient has some acute symptoms related to influenza or when influenza is prevalent in that region, when patient has high risk of developing pneumonia due to secondary infections as in diabetes, COPD, asthma, immunocompromised states, chronic renal or hepatic disease and neoplastic conditions. So, these drugs (oseltamivir or other related drugs) are not applicable to every case of influenza but about $25 \%$ GPs did not agree with this point (Table 2). ${ }^{13,16}$

In chicken pox, only immunocompromised patients need antiviral drugs. ${ }^{17,18}$ However $>50 \%$ GPs were unaware of this fact and $30 \%$ of them agreed that they treated all cases of chicken pox. Reverse is the case of Herpes zoster disease in which antiviral drugs are indicated even in immunocompetent patients as these can still develop postherpetic neuralgia. ${ }^{19,20}$ However many of these GPs didn't treat all cases of herpes-zoster as well as herpes genitalis with antiviral drugs (Table 3).

Finally, management of HBV and HCV infection requires thorough knowledge of the disease, hence these patients have to be referred to consultant physician or hepatologist for their expert opinion and management. But many MBBS and BHMS practitioners claimed that they treated these conditions on their own (Table 3).

Majority of GPs updated their knowledge by CMEs and only few GPs updated their knowledge by medical journals, internet and combinations of these three modalities. (Figure 1) Ideally to get the proper update on current medical practises and guidelines, they should utilize all these modalities.

\section{Positive findings}

Majority of GPs (90\%) agreed that antiviral drugs are not effective in bacterial infections. Most of GPs even agreed that every GP should have basic knowledge about common viral infections.

H1N1 infection and dengue fever can be complicated within few days and can rapidly produce epidemic in the community. Hence immediate reporting of these infections has to be done. ${ }^{21-23}$ Most of the GPs (83\%) were convinced with this point (Table 2).

Majority of GPs didn't treat all cases of influenza by oseltamivir and related drugs (Table 3) which is a correct practice. ${ }^{24-26}$ Anti-viral drugs are not as safer as antibacterial drugs. Some of these have serious side effects like bone marrow suppression, neuropsychiatric symptoms, allergic reactions, hepatotoxicity and renal toxicity etc. ${ }^{1,7}$ Therefore one should be cautious while prescribing these drugs and should have an adequate knowledge regarding identification of correct case to which antiviral drugs are clearly indicated. For this reason, general practitioners should have basic knowledge about these commonly prescribed antiviral drugs and their use in viral infections. In this study, this knowledge was lacking which has been reflected in their attitude and practice also.

\section{CONCLUSION}

Keeping some questions aside, significant number of study participants (GPs) gave incorrect answers to most of the questions which could not be ignored. Therefore, authors conclude that:

1. GPs have significantly poor knowledge, attitude and practices about use of antiviral drugs in viral infections.

2. There is no significant difference between different categories of GPs regarding the same.

Proper informative lectures must be given through CMEs, Seminars or conferences to all GPs about rational use of antiviral drugs. Irrationality of such prescriptions should be severely penalized to avoid future consequences on health, economy and patient's faith. GPs should update their knowledge through all modalities available for the same. 


\section{ACKNOWLEDGEMENTS}

Authors would like to thank all general practitioners who have participated in this study.

Funding: No funding sources Conflict of interest: None declared

Ethical approval: The study was approved by the Institutional Ethics Committee

\section{REFERENCES}

1. Raymund R, Razonable, MD. Antiviral Drugs for Viruses Other Than Human Immunodeficiency Virus. Mayo Clinic Proc. 2011:86(10):1009-26.

2. Centers for Disease Control and Prevention. Recommended adult immunization schedule, United States; 2016. Available at: www.cdc.gov/vaccines/schedules/downloads/adult/ad ult-schedule.pdf. Accessed 31 January 2018.

3. Gosselin V, Généreux $\mathrm{M}$, Gagneur $\mathrm{A}$, Petit $\mathrm{G}$. Effectiveness of rotavirus vaccine in preventing severe gastroenteritis in young children according to socioeconomic status. Hum Vaccin Immunother. 2016;12(10):2572-9.

4. Mrozek-Budzyn D, Kieltyka A, Majewska R, Augustyniak M. The effectiveness of rotavirus vaccine in preventing acute gastroenteritis during rotavirus seasons among Polish children. Arch Med Sci: AMS. 2016:12(3):614.

5. Velázquez RF, Linhares AC, Muñoz S, Seron P, Lorca $\mathrm{P}$, DeAntonio $\mathrm{R}$, et al. Efficacy, safety and effectiveness of licensed rotavirus vaccines: a systematic review and meta-analysis for Latin America and the Caribbean. BMC Pediatr. 2017;17(1):14.

6. Beri SG, Pandit VA, Khade KS, Sarda KD. The Pattern of Drug Use in Acute Fever by General Practitioners (GPs) in Pune City, India. J Clin Diagn Res. 2013;7(3):467.

7. Antiviral drugs. In: Tripathi KD. Essentials of Medical Pharmacology. $7^{\text {th }}$ Ed. Jaypee Brothers Medical Publishers; 2013:798-815.

8. Askarian M, Danaei M, Vakili V. Knowledge, attitudes, and practices regarding pandemic H1N1 influenza among medical and dental residents and fellowships in Shiraz, Iran. Int $\mathbf{J}$ Prev Med. 2013:4(4):396.

9. Gaglia Jr MA, Cook RL, Kraemer KL, Rothberg MB. Patient knowledge and attitudes about antiviral medication and vaccination for influenza in an internal medicine clinic. Clin Infect Dis. 2007:45(9):1182-8.

10. Zachary KC. Treatment of Seasonal Influenza in Adults. Available at: http://www.uptodate.com/contents/treatment-ofseasonal-influenza-in-

adults?detectedLanguage $=$ enandsource $=$ search_result andsearch=influenzaandselectedTitle $=1 \% 7 \mathrm{E} 150$ andp rovider=noProvider\#H13/ Accessed 31 January 2018.
11. Harper SA, Bradley JS, Englund JA, File TM, Gravenstein S, Hayden FG, et al. Seasonal influenza in adults and children-diagnosis, treatment, chemoprophylaxis, and institutional outbreak management: clinical practice guidelines of the Infectious Diseases Society of America. Clin Infect Dis. 2009:1003-32.

12. Farrukee R, Hurt AC. Antiviral Drugs for the Treatment and Prevention of Influenza. Curr Treat Options Infect Dis. 2017:9(3):318-32.

13. Stiver G. The treatment of influenza with antiviral drugs. Can Med Assoc J. 2003:168(1):49-57.

14. Institute of Medicine (US) Committee on Implementation of Antiviral Medication Strategies for an Influenza Pandemic. Antivirals for Pandemic Influenza: Guidance on Developing a Distribution and Dispensing Program. Washington (DC): National Academies Press (US); 2008. Available at: https://www.ncbi.nlm.nih.gov/books/NBK214504/. Accessed 31 January 2018.

15. WHO. Antiviral drugs for pandemic (H1N1): definitions and use. 2009. Available at: www.who.int/csr/disease/swineflu/frequently_asked_ questions/antivirals/definitions_use/en/. Accessed 31 January 2018

16. Allen UD, Aoki FY, Stiver HG. The use of antiviral drugs for influenza: recommended guidelines for practitioners. Can J Infect Dis Med Microbiol. 2006;17(5):273-84.

17. Straus SE, Ostrove JM, InchauspÉ G, Felser JM, Freifeld A, Croen KD, et al. Varicella-zoster virus infections: biology, natural history, treatment, and prevention. Ann Intern Med. 1988:108(2):221-37.

18. Kempf W, Meylan P, Gerber S, Aebi C, Agosti R, Buchner $S$, et al. Swiss recommendations for the management of varicella zoster virus infections. Swiss Med Wkly. 2007;137(17/18):239.

19. Stankus SJ, Dlugopolski M, Packer D. Management of herpes zoster (shingles) and postherpetic neuralgia. Am Fam Physician. 2000;61(8):2437-44.

20. Dworkin RH, Johnson RW, Breuer J, Gnann JW, Levin MJ, Backonja M, et al. Recommendations for the management of herpes zoster. Clin Infect Dis. 2007;44(1):S1-26.

21. Notification of dengue cases. New Delhi: Ministry of Health and Family Welfare, Govt. of India; 2018. Available at: http://nvbdcp.gov.in/Doc/notificationof-Denuge-Cases-June2016.pdf. Accessed 31 January 2018.

22. Das S, Sarfraz A, Jaiswal N, Das P. Impediments of reporting dengue cases in India. J Infect Public Health. 2017;10(5):494-8.

23. Hanvoravongchai P, Coker R. Early reporting of pandemic flu and the challenge of global surveillance: a lesson for Southeast Asia. Southeast Asian J Trop Med Public Health. 2011;42(5):1093.

24. Michiels B, Van Puyenbroeck K, Verhoeven V, Vermeire E, Coenen S. The value of neuraminidase inhibitors for the prevention and treatment of seasonal 
influenza: a systematic review of systematic reviews. PloS one. 2013;8(4):e60348.

25. Ebell MH, Call M, Shinholser J. Effectiveness of oseltamivir in adults: a meta-analysis of published and unpublished clinical trials. J Fam Pract. 2012;30(2):125-33.

26. Jefferson T, Jones MA, Doshi P, Del Mar CB, Hama $\mathrm{R}$, Thompson $\mathrm{M}$, et al. Neuraminidase inhibitors for preventing and treating influenza in healthy adults and children. Sao Paulo Med J. 2014;132(4):256-7.

Cite this article as: Beri SG, Bhide HS, Dhande PP, Raman A. Knowledge, attitude and practices of general practitioners about use of antiviral drugs in viral infections other than HIV. Int J Basic Clin Pharmacol 2018;7:1285-90. 